\title{
Synergistic and threshold effects of $G H 1$ and $G H R$ promoter size variation on body growth and fat accrual in young Nelore (Bos indicus) bulls
}

\author{
M.A. Dani ${ }^{1,2}$, M. von Cube ${ }^{3}$, I.L. Freire ${ }^{4}$, L. Suguisawa ${ }^{5}$, C. Fischer ${ }^{3}$, \\ S.U. Dani ${ }^{1,6,7}$ \\ ${ }^{1}$ Excegen Genética S.A. and Coarana Biotecnologia Ltda., Vale do Acangau, \\ Paracatu, MG, Brasil \\ ${ }^{2}$ Institute of Physiology, University of Göttingen Medical School, \\ Göttingen, Germany \\ ${ }^{3}$ Institute of Human Genetics, University of Heidelberg, Heidelberg, Germany \\ ${ }^{4}$ Programa de Engenharia de Defesa, Instituto Militar de Engenharia, \\ Rio de Janeiro, RJ, Brasil \\ ${ }^{5}$ Designer Genes Technologies Brasil, Presidente Prudente, SP, Brasil \\ ${ }^{6}$ Genon Genética Ltda., Ribeirão Preto, SP, Brasil \\ ${ }^{7}$ Department of Internal Medicine I and Clinical Chemistry, \\ Heidelberg University Hospital, Heidelberg, Germany \\ Corresponding author: S.U. Dani \\ E-mail: sergio.dani@med.uni-heidelberg.de
}

Genet. Mol. Res. 11 (2): 1783-1798 (2012)

Received March 13, 2012

Accepted June 1, 2012

Published June 29, 2012

DOI http://dx.doi.org/10.4238/2012.June.29.11

ABSTRACT. A synergistic effect in the somatotropic axis (GH1-GHR$I G F 1$ ) was observed in 736 young Nelore (Bos indicus) bulls under ad libitum grass feeding conditions on irrigated pasture in central Brazil. Stepwise substitution of shorter alleles of the promoter region of the growth hormone gene (GH1) and the P1 promoter of the $G H 1$ receptor gene $(G H R)$ with longer alleles was associated with significantly increased body weight gain (W550, weight at age 550 days; ADG, average daily gain) and fat accrual (FAT, rib eye fat thickness). A threshold effect on ADG was associated with allele size variation at the 
GH1. A best fit model indicated a 3- to 6-fold effect of $G H 1$ variation on ADG, when compared to the variation at the GHR and a known microsatellite at the somatomedin gene (IGF1, insulin-like growth factor 1). A threshold effect on FAT was associated with substitution of the short GHR allele by the longer GHR alleles; the effect of the GHR variation on FAT was 10-fold that of the variation at the GHI and IGFI loci. Among the 10 GH1-GHR-IGF1 multi-genotypes identified, the predominant genotype was homozygous for the large GH1 promoter (long/long, G2/G2 or domestic type), short GHR promoter (short/short or wild type), and short IGF1 microsatellite (short/short or wild type). This predominant multi-genotype suggests that selection pressure in the Nelore breed has been directed towards high ADG and W550, and low FAT. Our results mirror previous findings in the oMtla-oGH transgenic mouse model, in which the level of somatotropic gene expression acts through a threshold mechanism, and low expression results in adipogenesis, while high expression increases body growth.

Key words: Somatotropic axis; Growth hormone gene; Bos indicus; Promoter region; Growth and fat accrual; Marker-assisted selection

\section{INTRODUCTION}

Growth hormone (GH1), GH1 receptor (GHR) and somatomedin (IGF1 - insulin-like growth factor 1) constitute the somatotropic axis, which controls metabolism, growth, development and aging in a wide range of animals (Berryman et al., 2008). In bovines, it has been shown that the somatotropic axis is functionally coordinated and sensitive to nutrient intake and GH1 (Smith et al., 2002; Butler et al., 2003; Radcliff et al., 2006). Mutations that reduce GH1 signaling have been shown to extend lifespan and increase longevity in similar ways as observed in diet restriction (DR) models (Shimokawa et al., 2003; Zha et al., 2008).

We have previously shown that the short, wild-type allele of the promoter region of the bovine $G H 1$ gene, G1, confers a thrifty phenotype under DR as observed in a drought season, as compared to the longer allele, G2 (Dani et al., 2010). This observation prompted us to study the associations between the GH1, GHR and $I G F 1$ genotypes and a number of growth and carcass traits of 1269 young Nelore bulls (Bos indicus) fed ad libitum on irrigated pasture.

The biallelic GH1 promoter polymorphism analyzed in this study is characterized by the presence of one (Rodrigues et al., 1998) or two (Gordon et al., 1983) AAG trinucleotides positioned, in tandem, 9 bp upstream of the TATA-box transcription control site of the GH1 promoter region. The longer allele, G2 has been originally described for Bos taurus cattle (Gordon et al., 1983), while the shorter allele, G1, has been observed in water buffaloes, Bubalus bubalis, and also in B. indicus and some tropically adapted B. taurus breeds (Rodrigues et al., 1998, 1999; Dani et al., 2010). Since molecular phylogenetics has shown that Bos and Bubalus share the same ancestor from some 5-8 million years ago (Ritz et al., 2000; MacEachern et al., 2009), we assume that $G 1$ is the ancient wild-type form, whereas $G 2$ is the mutated, domestic form.

The multiallelic GHR polymorphism studied here is a polymorphic TG-repeat mic- 
rosatellite located $90 \mathrm{bp}$ upstream of a major transcription start site in the $\mathrm{P} 1$ promoter of the GHR gene on bovine chromosome 20 (Lucy et al., 1998). A shorter allele with 11 consecutive TG $\left.\left[(\mathrm{TG})_{11}\right)\right]$ is common in $B$. indicus cattle, whereas longer $\left[(\mathrm{TG})_{>11}\right]$, especially 16 - to 20-TG-repeat alleles predominate in B. taurus breeds (Hale et al., 2000).

At the IGFI locus, the polymorphic microsatellite (CA)n located in the 5 '-flanking region of the $I G F 1$ gene (Kirkpatrick, 1992) has been widely employed in studies targeted towards the localization of quantitative trait loci. Of the known 4 alleles, the shorter allele has never been observed in taurine breeds.

\section{MATERIAL AND METHODS}

\section{Field conditions, feeding test}

The experimental Nelore (B. indicus) herd was a commercial herd owned by Perdizes Farm (Quilombo E\&P Ltda.) and other owners; it included 1065 standard Nelore and 204 polled Nelore bulls. Animals were handled and managed according to guidelines and standard practices of the annual feeding test at the Perdizes Farm in Jaraguari, MS, Brazil (20²2’29.78’S, $\left.54^{\circ} 18^{\prime} 52.66^{\prime \prime} \mathrm{W}\right)$. These included pasture-feeding ad libitum in an irrigated pasture on quartzarenic neosol, with water and mineral supplementation. Green mass was available all year long, although some seasonal variation in grass productivity apparently occurred. Animals entered the feeding test directly after weaning at ages varying between 8 and 10 months and were discharged 365 days later.

\section{Growth and carcass traits}

Measures of growth and carcass traits were obtained at 3-month intervals. Animals were weighed at entry into the trial. Average daily gain (ADG, in $g$ ) was calculated after an adaptation period of 56 days. Weight ( $\mathrm{W}$, in $\mathrm{kg}$ ) was adjusted to 550 days of age according to Equation 1:

$$
\mathrm{W} 550=[((\mathrm{AW} 365-\mathrm{BW}) / \mathrm{AEFT}) * 550+\mathrm{BW}], \quad(\text { Equation } 1)
$$

with AW365 being actual weight, in kg, after the end of 365 days of feeding test; BW, birth weight, in kg; AEFT, actual age, in days, at the end of the feeding test. Rib eye area (REA, in $\mathrm{cm}^{2}$ ), subcutaneous fat thickness (FAT, in $\mathrm{mm}$ ) and marbling score (MARB) were obtained ultrasonographically. MARB information was available for 358 bulls, all of which were genotyped for $I G F 1$. Scrotal circumference $(\mathrm{SC}$, in $\mathrm{cm}$ ) was obtained at final weighing.

\section{Samples and genotyping}

The bulls were genotyped with respect to the GH1, GHR and $I G F 1$ polymorphic sites as shown in Table 1. All bulls were genotyped for GH1, GHR, but only 460 bulls were genotyped for $I G F 1$. Nasal swabs were collected in the field and stored in ethanol. DNA from 40 $\mu \mathrm{L}$ nasal swab was extracted using the DNA IQ System (Promega), according to manufacturer instructions. Extracted DNA was dissolved in deionized water to a final working concentra- 
tion $(50 \mathrm{ng} / \mu \mathrm{L})$. PCR genotyping was carried out with the primer pairs as listed in Table 1 (forward primers were FAM-labeled). The PCR mixture included $2 \mathrm{mM} \mathrm{MgCl}, 0.375 \mathrm{mM}$ of each dNTP, 1 pmoL of each forward and reverse primer, $1 \mathrm{U}^{\text {GenoTaq }}{ }^{\mathbb{B}}(5 \mathrm{U} / \mu \mathrm{L}$; Genon Ltda., Brazil) and 50 ng DNA template, in a $20-\mu \mathrm{L}$ total reaction volume overlayed with mineral oil. PCR was carried out in a Mastercycler PCR thermocycler (Eppendorf, Germany) with the following profile: hot start at $94^{\circ} \mathrm{C}, 10 \mathrm{~min} ; 35$ cycles of $94^{\circ} \mathrm{C}$ for $1 \mathrm{~min}, 58^{\circ} \mathrm{C}$ for $1 \mathrm{~min}$ and $72^{\circ} \mathrm{C}$ for $1 \mathrm{~min}$, and a final extension at $72^{\circ} \mathrm{C}$ for $4 \mathrm{~min}$. PCR products were separated and analyzed by polyacrylamide gel electrophoresis (PAGE) in a MegaBACE 1000 capillary sequencer (GE Healthcare Life Sciences, USA). Electropherograms were analyzed using the Fragment Profiler software, and the results were deposited in our data bank for further statistical analyses. To rule out any confounding effects of the L127V variant site (Lucy et al., 1991) on production traits (Lucy et al., 1991; Schlee et al., 1994; Lee et al., 1996; Grochowska et al., 2001; Sorensen et al., 2002; Paz, 2002; Ge et al., 2003), we performed a PCR-RFLP genotyping of exon-5 of the GH1, according to Schlee and co-workers (1994) in a subset of 85 Nelore bulls representative of their respective sibling groups, and taken at random out of our series of experimental animals encompassing all three $G 1$ and $G 2$ genotypes. PCR-RFLP AluI (10 U/ $\mu \mathrm{L}$; Gibco BRL) digests were separated by PAGE followed by silver staining as described by Sanguinetti and co-workers (1994). Possible confounding effects of the GH1 gene L127V variant site on productive traits were ruled out because the whole experimental herd was monomorphic, $L L$. The fixation of the $L L$ genotype in our herd confirms previous reports on $L$ allele fixation in the Brazilian Nelore population (Rosa et al., 1996; Rosa, 1997) or the Zebu population - Brahman breed (DeNise and Regitano, 1996). Absence of the $V$ allele in the Zebu population in Brazil can be attributed to the small number of animals that gave origin to the Brazilian herd and by the very low frequency of this allele (Mitra et al., 1995).

\begin{tabular}{|c|c|c|c|c|}
\hline Gene, region & $\begin{array}{l}\text { Genotyping method and } \\
\text { PCR primer sequences }\end{array}$ & $\begin{array}{l}\text { Cromosomal location } \\
\text { (chromosome number) }\end{array}$ & $\begin{array}{l}\text { Alleles } \\
\text { (sizes, in bp, } \\
\text { or names) }\end{array}$ & References \\
\hline$G H 1$, promoter region & $\begin{array}{l}\text { AFLP } \\
\text { F: 5'-TGGCAGTGGAGACGGGATGATG-3' } \\
\text { R: 5'-CCTCCCCAAATCAATTACATTTTCTC-3' }\end{array}$ & 19 & $\begin{array}{l}193(w t) \\
196\end{array}$ & Dani et al. (2010) \\
\hline GH1, exon (L127V) & $\begin{array}{l}\text { RFLP }(\text { AluI }) \\
\text { F: 5'-GTGGGCTTGGGGAGACAGAT-3' } \\
\text { R: 5'-GTCGTCACTGCGCATGTTTG-3' }\end{array}$ & 19 & $\begin{array}{l}\text { L (wt) } \\
\text { V }\end{array}$ & $\begin{array}{l}\text { Lucy et al. (1991); } \\
\text { Schlee et al. (1994) }\end{array}$ \\
\hline$G H R$, promoter region & $\begin{array}{l}\text { AFLP } \\
\text { F: 5'-CCCTAATCTTTTCTGGTACCAGG-3' } \\
\text { R: 5'-CCTGCTGGGCCATTTTTATACC-3' }\end{array}$ & 20 & $\begin{array}{l}93 \text { (wt) } \\
103 \\
105 \\
107\end{array}$ & Lucy et al. (1998)* \\
\hline$I G F I$, microsatellite & $\begin{array}{l}\text { AFLP } \\
\text { F: 5'-GCTTGGATGGACCATGTTG-3' } \\
\text { R: 5'-CACTTGAGGGGCAAATGATT-3' }\end{array}$ & 5 & $\begin{array}{l}225(w t) \\
227 \\
229\end{array}$ & Bishop et al. (1994) \\
\hline
\end{tabular}

$\mathrm{AFLP}=$ amplified fragment length polymorphism; RFLP = restriction fragment length polymorphism; $\mathrm{F}=$ forward and $\mathrm{R}=$ reverse $\left(\mathrm{F}\right.$-primers used in AFLP analyses were FAM-labeled); $\mathrm{wt}=$ wild type. ${ }^{*}$ The GHR-F primer has been shortened by three nucleotides (5'-GTG) as compared to the Lucy et al. (1998) primer. It follows the corresponding allele nomenclature change (Lucy et al., 1998; this paper): 94-(91)/(96)-93/104-(101)/106-103/108-105/(110)-107/112-(109) (in parentheses: alleles that have not been identified in the respective studies). 


\section{Statistical analyses}

Gene frequency $\left(\mathrm{x}_{\mathrm{i}}\right)$, for the $i$ allele, and genotypic frequency $\left(\mathrm{x}_{\mathrm{ii}}\right)$, for the $i i$ genotype were estimated for the population, according to Equations 2 and 3:

$$
\begin{array}{cc}
\mathrm{x}_{\mathrm{i}}=\left[\left(2 \mathrm{n}_{\mathrm{ii}}+\sum \mathrm{n}_{\mathrm{ij}}\right) / 2 \mathrm{n}\right], & \text { (Equation 2) } \\
\mathrm{x}_{\mathrm{ii}}=\left[\mathrm{n}_{\mathrm{ii}} / \mathrm{n}\right], & \text { (Equation 3) }
\end{array}
$$

where $n_{i i}$ and $n_{i j}$ refer to the number of homozygotes and heterozygotes observed for the allele $i$, respectively; $n$ refers to the number of individuals. Growth traits were analyzed by the least squares method, using the GLM procedure of $\mathrm{SAS}^{\circledR}$ (Statistical Analysis System, 2000). Genetic association tests, analyses of variance and box and whisker plots were analyzed with IBM SPSS V19 (IBM Corp., Armonk, NY, USA). To rule out possible confounding effects due to paternity, analyses were performed within and between groups of the sires' half-siblings.

\section{Definition of wild-type and domestic type alleles of $G H 1, G H R$ and $I G F 1$}

The short alleles of each $G H 1, G H R$ and $I G F 1$ were considered wild types, whereas the longer alleles were the domestic types. Rare longer alleles were pooled and regarded as domestic type irrespective of their size differences. The significance of the observed effect was measured by the Fisher exact test.

\section{Best-fit model}

The effect of an allele $a$ on a carcass trait $t$, in the context of the alleles for GH1, GHR, and $I G F 1$ was studied by the best-fit values of $t$ in the sets of bulls having 0,1 , or 2 copies of $a$, respectively, called $v_{a, t, 0}, v_{a, t, 1}$ and $v_{2 a, t, 2}$ here. The best-fit model is the linear equation that minimizes the error between the values of $t$ in the set.

\section{RESULTS}

We detected 10 GH1-GHR-IGF1 multi-genotypes in our Nelore population, with the predominant multi-genotype being homozygous for the large GH1 promoter (large/large, G2/ $G 2$ or domestic type), short GHR promoter (short/short or wild-type), and short IGF1 microsatellite (short/short or wild type). The L/L variant of the L127V GH1 polymorphic site was fixed in the population. The single-allele frequencies are shown in Table 2, and the growth and carcass traits are shown in Table 3.

The Nelore bulls were either standard $(\mathrm{N}=1065,84 \%)$ or polled $(\mathrm{N}=204,16 \%)$. The polled trait is believed to have been introgressed into the Nelore population from cattle of European origin, and the polled Nelore group had a higher frequency of domestic alleles. Thus, we took this group as proxy to domestic cattle (B. taurus), whereas the standard Nelore was taken as a proxy to the semi-domesticated or wild-type cattle (B. indicus). Table 2 shows the genotypic differences between these 2 Nelore sub-groups.

A pairwise comparison showed that the polled Nelore differed from the standard 


Table 2. Estimated allele frequencies (P) for the loci studied.
\begin{tabular}{lccccccc}
\hline Gene & $\mathrm{N}$ & Allele & $\mathrm{P}$ & Standard Nelore & $\mathrm{P}$ & Polled Nelore & $\mathrm{P}$ \\
\hline GHI (promoter) & 2538 & $193(\mathrm{wt})$ & 0.048 & 103 & 0.048 & 9 & 0.022 \\
& & 196 & 0.956 & 2027 & 0.952 & 399 & 0.978 \\
GHI (L127V) & 170 & $\mathrm{~L}(\mathrm{wt})$ & 1.000 & $(2130)$ & 1.000 & $(408)$ & 1.000 \\
& & $\mathrm{~V}$ & - & - & - & - & - \\
GHR (promoter) & 2538 & $93(\mathrm{wt})$ & 0.914 & 1987 & 0.933 & 336 & 0.824 \\
& & 103 & 0.003 & 6 & 0.003 & 1 & 0.002 \\
& & 105 & 0.082 & 135 & 0.063 & 70 & 0.172 \\
& & 107 & 0.001 & 2 & 0.001 & 1 & 0.002 \\
IGFI (microsatellite) & 920 & $225(\mathrm{wt})$ & 0.834 & 650 & 0.827 & 119 & 0.875 \\
& & 227 & 0.009 & 7 & 0.009 & 1 & 0.007 \\
& & 229 & 0.158 & 129 & 0.164 & 16 & 0.118 \\
\hline
\end{tabular}

$\mathrm{wt}=$ wild type.

Table 3. Carcass and growth traits of 1269 young Nelore bulls in the feeding test.

\begin{tabular}{|c|c|c|c|c|c|}
\hline Traits & Minimum & Maximum & Median & Average & SD \\
\hline W550 & 276.8 & 509.9 & 382.4 & 383.4 & 30.9 \\
\hline $\mathrm{ADG}$ & 201 & 959 & 633 & 633 & 897 \\
\hline $\mathrm{SC}$ & 20.5 & 38.2 & 28.9 & 28.8 & 3.1 \\
\hline REA & 36.9 & 79.9 & 55.9 & 56.5 & 6.4 \\
\hline FAT & 0.587 & 5.392 & 2.229 & 2.124 & 0.668 \\
\hline MARB & 1.03 & 4.05 & 2.29 & 2.36 & 0.45 \\
\hline FAT/ADWG & 0.778 & 8.958 & 3.338 & 3.409 & 1.133 \\
\hline FAT/W550 & 0.001 & 0.015 & 0.005 & 0.006 & 0.002 \\
\hline FAT/REA & 0.009 & 0.104 & 0.036 & 0.038 & 0.013 \\
\hline REA/ADWG & 55 & 209 & 89 & 91 & 16 \\
\hline REA/W550 & 0.105 & 0.198 & 0.147 & 0.148 & 0.0149 \\
\hline
\end{tabular}

W550 = weight, in kg, adjusted to 550 days of age; $\mathrm{ADG}=$ average daily weight gain, in $\mathrm{g} /$ day; $\mathrm{SC}=$ scrotal circumpherence, in $\mathrm{cm}$; REA = rib eye area, in $\mathrm{cm}^{2} ; \mathrm{FAT}=$ rib eye fat thickness by ultrasound, in mm; MARB = marbling score by ultrasound. $\mathrm{SD}=$ standard deviation.

Nelore in W550, SC and REA $(\mathrm{P}<0.001)$, with the polled Nelore values significantly higher by $10.6 \mathrm{~kg}, 1.1 \mathrm{~cm}$, and $2.5 \mathrm{~cm}^{2}$, respectively, as compared to the standard Nelore. Also, there were significant genotypic differences in $G H 1$ and $G H R$ allele frequencies $(\mathrm{P}<0.001)$, although not in $I G F 1$ or $L 127 \mathrm{~V}$ allele frequencies (Table 2). There were no significant differences in FAT between these groups. However, the relatively small number of polled Nelore bulls and the lower frequencies of wild-type alleles in this group hindered a comparison between distinct genotype classes. Within the standard Nelore group, a three-factorial analysis of variance showed that differences in FAT were significantly associated with $G H R(\mathrm{P}=0.001)$ and the interaction $G H 1 * G H R(\mathrm{P}=0.021)$. Differences in MARB were weakly associated with the interaction $G H 1 * G H R(\mathrm{P}=0.037)$ and strongly associated with the interaction $G H 1$ * GHR * IGF1 $(\mathrm{P}<0.001)$. However, the data did not show a normal distribution, and under the conditions of non-parametric tests, no significant differences were observed.

We then set out to normalize the data. Of the 1269 bulls, $766(60 \%)$ were fathered by 20 sires, whereas $503(40 \%)$ were fathered by 152 sires. The number of bulls/sires in the first subgroup varied from 14 to 112, whereas in the latter group it varied from 1 to 13 bulls. Sires were unknown for 99 bulls. Figure 1 shows the distribution of W550 of 736 bulls from 18 sires who fathered at least 18 bulls in the feeding test. The half-sib progeny of these sires differed significantly in W550, ADG, SC, REA, and FAT $(\mathrm{P}<0.001)$ and MARB $(\mathrm{P}=0.004)$ (one-way analysis of variance). 


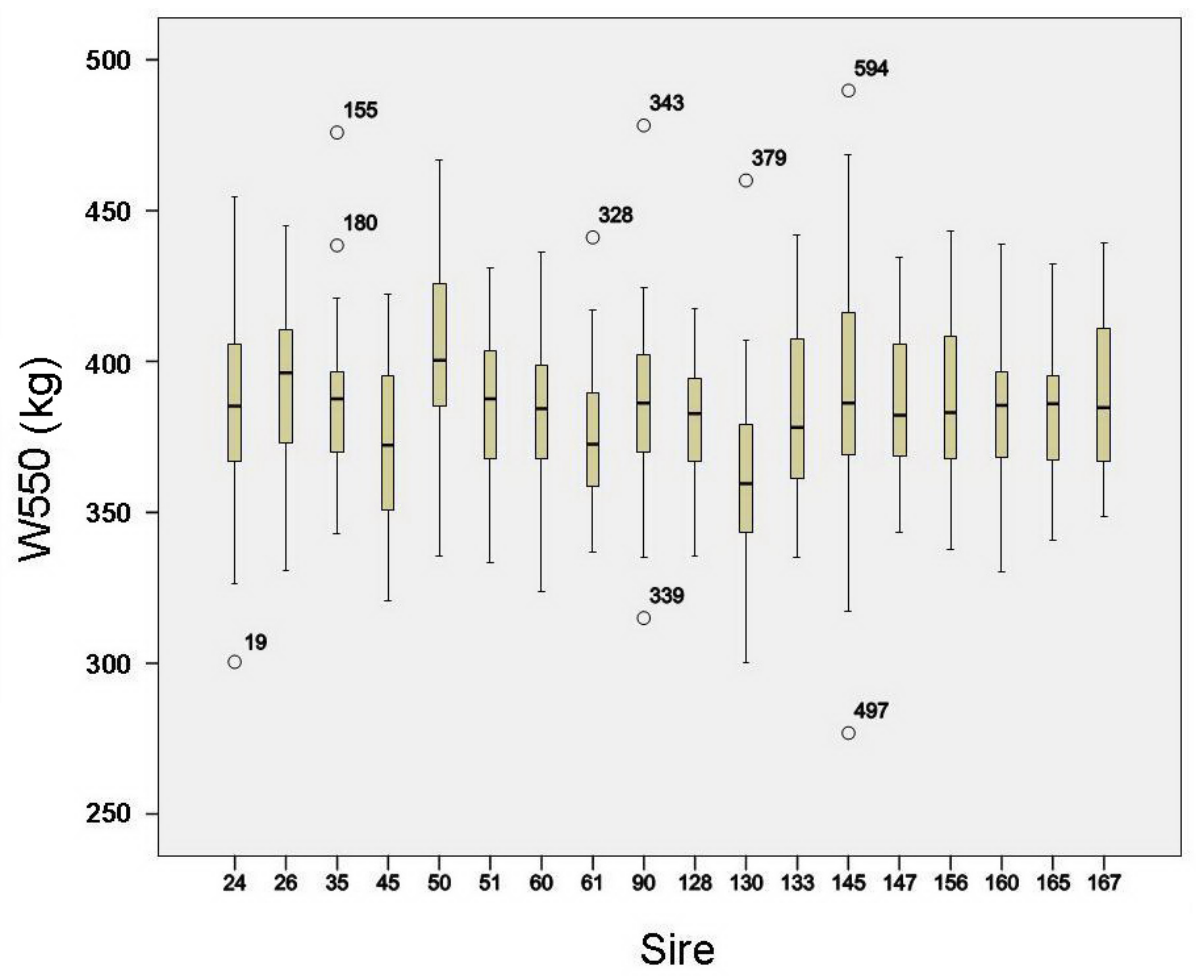

Figure 1. Average W550 distribution of 736 half-sib bulls grouped per sire progeny. Depicted is the progeny of sires that fathered at least 18 half-sib bulls in the feeding test.

To eliminate the bias due to parental origin, we distributed the bulls with no missing genotypic and phenotypic information into genotype classes, and we then calculated the average growth and carcass traits for each half-sib group within each pooled genotype class. The normalized genotype classes and respective mean values of selected growth and carcass traits are depicted in Table 4.

\begin{tabular}{|c|c|c|c|c|c|c|c|c|}
\hline \multicolumn{2}{|c|}{ Genotype classes } & \multirow{2}{*}{$\frac{N(\text { bulls/pools) }}{7 / 4}$} & \multirow{2}{*}{$\frac{\mathrm{W} 550(\mathrm{~kg})}{386}$} & \multirow{2}{*}{$\frac{\mathrm{ADG}(\mathrm{g} / \text { day })}{634}$} & \multirow{2}{*}{$\frac{\text { FAT }(\mathrm{mm})}{1.71}$} & \multirow{2}{*}{$\frac{\text { MARB }}{2.6}$} & \multirow{2}{*}{$\frac{\mathrm{SC}(\mathrm{cm})}{29}$} & \multirow{2}{*}{$\frac{\operatorname{REA}\left(\mathrm{cm}^{2}\right)}{57}$} \\
\hline 1 & $\mathrm{~s} / \mathrm{s}-\mathrm{s} / \mathrm{s}-\mathrm{s} / \mathrm{s}$ & & & & & & & \\
\hline 2 & $\mathrm{~s} / 1-\mathrm{s} / \mathrm{s}-\mathrm{s} / \mathrm{s}$ & $41 / 17$ & 381 & 630 & 1.87 & 2.3 & 28 & 57 \\
\hline 3 & $\mathrm{~s} / 1-\mathrm{s} / \mathrm{s}-\mathrm{s} / 1$ & $23 / 7$ & 382 & 676 & 1.83 & 2.6 & 29 & 56 \\
\hline 4 & $\mathrm{~s} / 1-\mathrm{s} / 1-\mathrm{s} / \mathrm{s}$ & $4 / 4$ & 410 & 644 & 2.43 & 2.4 & 29 & 55 \\
\hline 5 & $\mathrm{~s} / 1-\mathrm{s} / 1-\mathrm{s} / 1$ & $3 / 3$ & 362 & 589 & 2.75 & 1.5 & 28 & 54 \\
\hline 6 & 1/1-s/s-s/s & $198 / 48$ & 391 & 658 & 1.84 & 2.3 & 28 & 57 \\
\hline 7 & 1/1-s/s-s/1 & $69 / 25$ & 384 & 650 & 1.95 & 2.3 & 29 & 56 \\
\hline 8 & 1/1-s/s-1/1 & $8 / 8$ & 392 & 657 & 1.76 & 2.4 & 28 & 53 \\
\hline 9 & $1 / 1-\mathrm{s} / 1-\mathrm{s} / \mathrm{s}$ & $73 / 28$ & 382 & 660 & 2.08 & 2.1 & 28 & 55 \\
\hline 10 & 1/1-s/1-s/1 & $33 / 20$ & 396 & 646 & 2.07 & 2.3 & 29 & 57 \\
\hline
\end{tabular}

$\mathrm{s}=$ short (wide type) allele; $1=$ long (domestic) allele. For other abbreviations, see legend to Table 3. 
A synergistic effect was observed in that the stepwise substitution of shorter alleles with longer alleles in the GH1-GHR-IGF1 axis was associated with increased W550, ADG and FAT. A threshold effect on ADG was associated with size variation at the GH1 locus. A simple best-fit model indicated a 3- to 6-fold effect of $G H 1$ variation on ADG, as compared to the variation at $G H R$ and $I G F 1$ loci, respectively. A threshold effect on FAT was associated with substitution of the short GHR allele by the longer GHR alleles. The effect of the GHR variation on FAT was 10-fold that of the variation at the GHI and IGF1 loci (Figure 2).
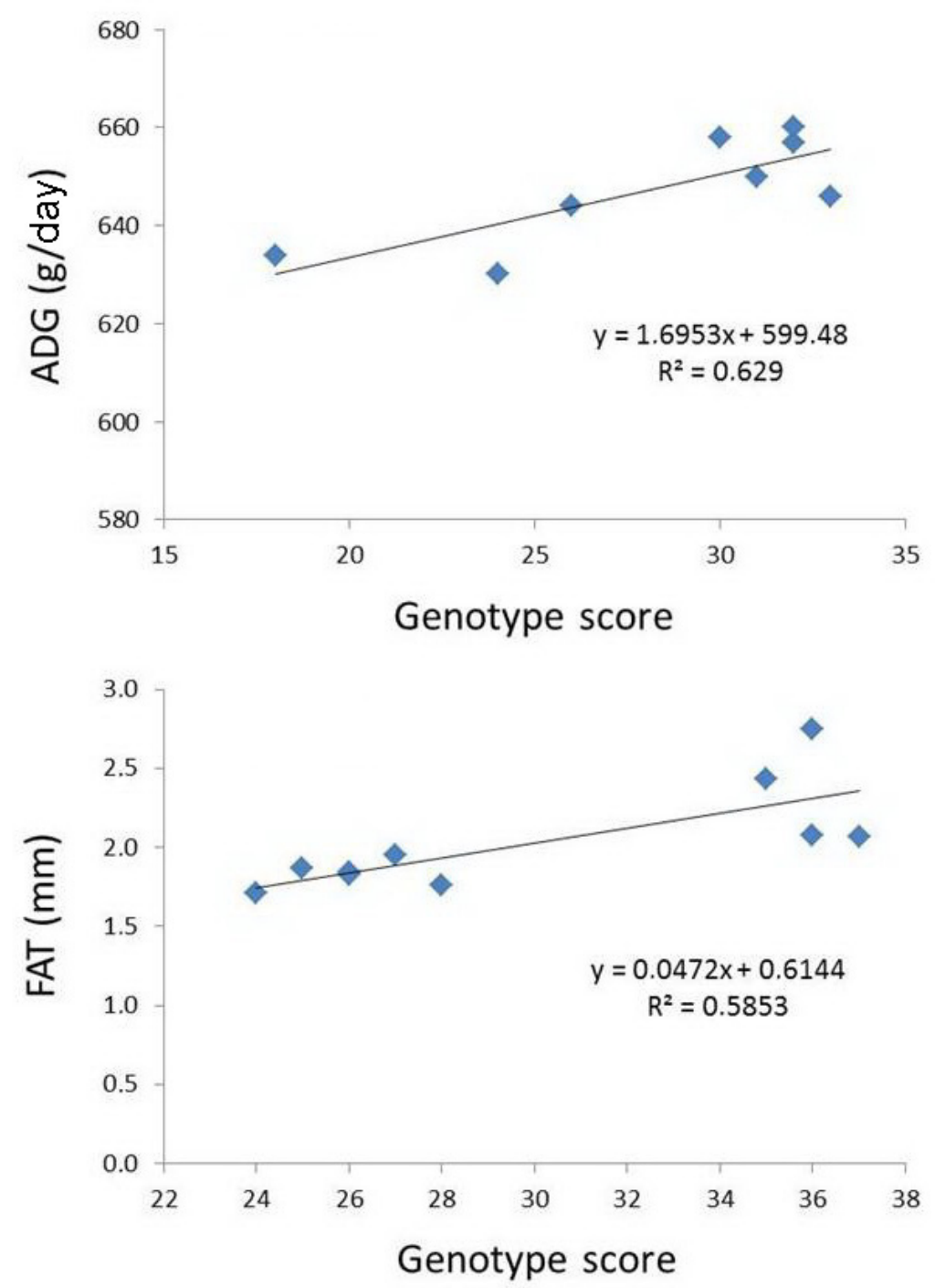

Figure 2. Best-fit models of genotype-phenotype associations in the ad libitum condition for average daily gain $(\mathrm{ADG})[((\mathrm{GH} 1 \mathrm{a}+\mathrm{GH} 1 \mathrm{~b}) * 6)+((\mathrm{GHRa}+\mathrm{GHRb}) * 2)+((\mathrm{IGF} 1 \mathrm{a}+\mathrm{IGF} 1 \mathrm{~b}) * 1)]$ and rib eye fat thickness $(\mathrm{FAT})$ $[((\mathrm{GH} 1 \mathrm{a}+\mathrm{GH} 1 \mathrm{~b}) * 1)+((\mathrm{GHRa}+\mathrm{GHR} b) * 10)+((\mathrm{IGF} 1 \mathrm{a}+\mathrm{IGF} 1 \mathrm{~b}) * 1)]$. Alleles $\mathrm{a}, \mathrm{b}=1$, if short or wild type; $\mathrm{a}, \mathrm{b}=2$, if long or domestic type. 
MARB was inversely correlated with FAT, but no significant correlation was found between MARB and ADG, W550 or any particular GH1-GHR-IGF1 genotype (Figure 3).

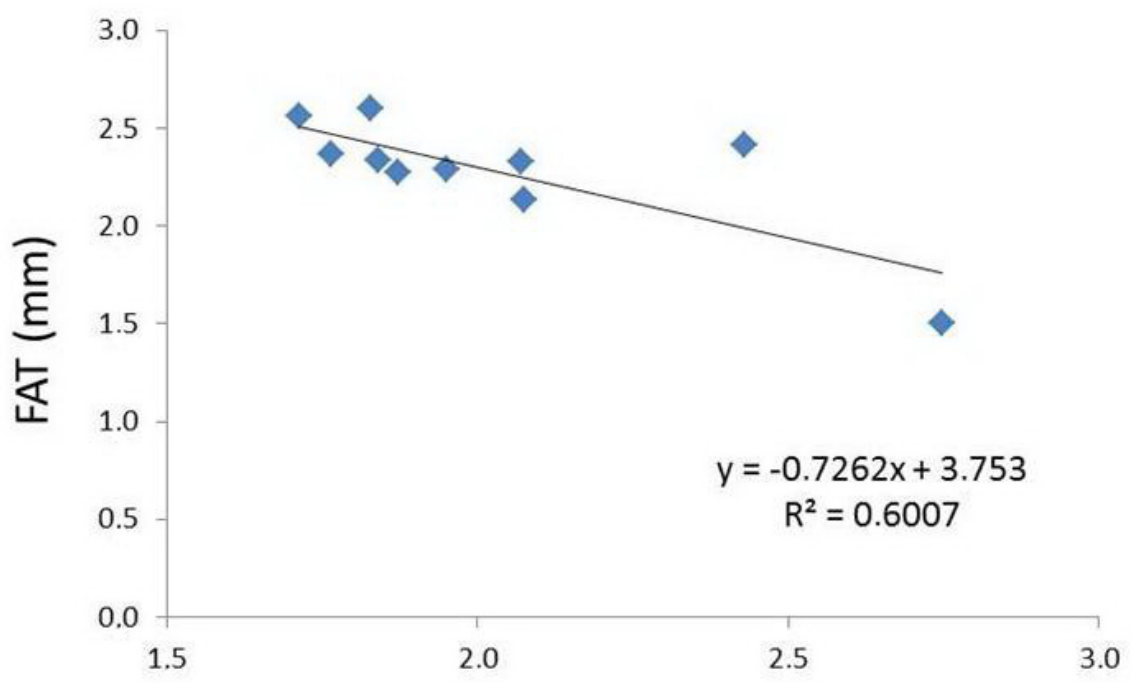

MARB score

Figure 3. Rib eye fat thickness (FAT) and marbling score (MARB) are inversely correlated across 10 genotypes of the GH1-GHR-IGF1 axis.

\section{DISCUSSION}

Associations of DNA polymorphisms and bovine growth and carcass traits have been reported for GH1 (Schlee et al., 1994; Lee et al., 1996; Rosa et al., 1996; Grochowska et al., 2001; Sorensen et al., 2002; Paz, 2002; Lima, 2003; Katoh et al., 2008; Ardiyanti et al., 2009; Matsuhashi et al., 2011), GHR (Hale et al., 2000; Ge et al., 2003; Garrett et al., 2008) and IGF1 (Ge et al., 2001; Li et al., 2004; Curi et al., 2005; Andrade et al., 2008; Maj et al., 2008; Kim et al., 2009; Islam et al., 2009; Reyna et al., 2010).

Most of these studies have been performed on European cattle (B. taurus), which is believed to have undergone a more intensive domestication as compared to Zebu cattle ( $B$. indicus). Also, almost all of these studies have focused on isolated effects of GH1, GHR or $I G F 1$, in different ad libitum conditions. In the present study, we examined the synergistic and threshold effects of the genotypic transitions in the GH1-GHR-IGF1 axis in the Brazilian Nelore bulls fed ad libitum on irrigated pasture.

Although the Nelore breed is usually considered as $B$. indicus, it does not constitute a genetically homogeneous population - perhaps reflecting the longitudinal diverse environmental realities in Brazil and also the genetic mixing with $B$. taurus breeds and other $B$. indicus breeds. This genetic mixing that occurred in the process of formation of the Nelore breed has been advantageous in the context of the diverse Brazilian environments, because the crossbred taurus-indicus and indicus-indicus usually show hybrid vigor.

In a genetic similarity study, we found that the Nelore population is divided into at 
least two genetically distinct populations, which we have classified as the "thrifty type" and the "demanding type" (Dani et al., 2008). At least one gene has been associated with the thrifty phenotype in DR conditions, namely the wild-type allele $G 1$ of the GH1 promoter region (Dani et al., 2010).

In expanding our analyses to the GH1-GHR-IGF1 axis in the present study, we found synergistic and threshold effects in that each stepwise substitution of a wild-type allele with a longer allele was associated with differentially increased weight gain and fat accrual in the ad libitum condition. Our results are in agreement with some isolated findings as reported in other studies, but also demonstrate novel aspects of regulation in the bovine somatotropic axis as follows.

\section{GH1 substitution effects}

Our own studies (Lima, 2003; Dani et al., 2010) indicate that substitution of $G 1$ with G2 results in significantly increased weight gain and increased hip height in the ad libitum conditions of feedlot experiments. Homozygous $G 2 / G 2$ Nelore bulls in a feedlot had an extra $34 \pm 20 \mathrm{~g} /$ day average weight gain during a 112 day feeding period, equivalent to an extra 10 $\pm 5 \mathrm{~kg}$ at 378 days of age, and were $2 \mathrm{~cm}$ taller as compared to $G 1 / G 2$ males at 378 days of age (Lima, 2003). Also, the results of a $G 1 / G 2 \times G 1 / G 2$ breeding test indicated that $G 1 / G 1$ and $G 2 / G 2$ full siblings can differ in weight at 365 days of age by as much as $50 \mathrm{~kg}$ (Dani et al., 2010). However, homozygous $G 2 / G 2$ heifers at 550 days of age in the pasture were only $6 \pm 4 \mathrm{~kg}$ heavier as compared to $G 1 / G 2$ heifers (Lima, 2003). Under more exacting DR, the G1 allele sustained growth better than the $G 2$ in young bulls (Dani et al., 2010). In the latter study, the trend towards better performance of $G 2 / G 2$, as observed in the more regular $a d$ libitum feedlot model, disappears in the pasture feeding model. Under the more exacting DR conditions, $G 1 / G 1$ cattle (and $G 1 / G 2$ cattle to a lesser extent) average better in postweaning growth or, more appropriately, they are more resilient to DR-related decreases in growth rates than their $G 2 / G 2$ counterparts. Under exacting DR, two $G 1$ alleles provided for maximal adaptation - as growth resilience and thriftiness - while one or two $G 2$ alleles were detrimental or abiotropic.

The present study indicates that the thrifty effect of the shorter $G H 1$ allele can be at least partly explained by downregulated growth and upregulated fat accrual in DR conditions. In the present study, we found that size variation at the GH1 locus was associated with a threshold effect on ADG. Our best-fit model indicated a 3- to 6-fold effect of $G H 1$ variation on ADG, as compared to the variation at $G H R$ and $I G F I$ loci, respectively. Our findings are in line with the observations made in the oMtla-oGH transgenic mouse model, where different levels of GH1 expression can be induced. In this model, chronic highly elevated expression of GH1 enhances overall body growth with minimal adipose accretion, while moderate levels of circulating GH1 fail to enhance body growth yet promote adipose deposition (Oberbauer et al., 2004). The lowest GH1 levels did not increase body size but did enlarge fat depots. The highest levels of circulating GH1 increased all forms of the GHR, IGF1, and hepatic lipoprotein lipase mRNA. The dissociation of GH1 effects on growth and adipogenesis as a function of circulating GH1 levels suggests that the level of GHR and IGF1 expression acts through a threshold mechanism and that low expression results in adipogenesis while high expression generates body growth. 


\section{GHR substitution effects}

Our results indicating a direct effect of the longer GHR alleles on growth and carcass traits are in partial agreement with those of Hale et al. (2000). These authors found an association of the short GHR allele with decreased growth in Angus steers. Contrasts for long/long homozygotes $v s$ short/long heterozygotes were significant for weaning weight and carcass weight. Approaching significance was the contrast for USDA marbling score, whereas no significant differences were detected for contrasts in birth weight, longissimus muscle area, or carcass fat depth. We did find an association of the large GHR alleles with W550, ADG and FAT, but this association was only visible after taking the synergistic effects of $G H 1$ and $I G F 1$ variation into account. The effect of GHR variation on FAT was 10-fold that of the variation at the GH1 and IGF1 loci (Figure 2). MARB was inversely correlated with FAT, but no significant correlation was found between MARB and ADG, W550 or any particular GH1-GHR-IGF1 genotype (Figure 3). It has been shown that FAT is more accurate than MARB in predicting fat content (Bullock et al.,1991; Belk et al., 1991), perhaps reflecting the fact that marbling is more directly influenced by a set of genes outside the somatotropic axis. Also, it is known that different cattle breeds differ in their ability to partition fat between the internal and the carcass depots (Sprinkle et al., 1998). Fat deposition in ectopic depots such as skeletal muscle and liver can cause lipotoxicity and impair insulin action. Conversely, expansion of subcutaneous adipose tissue may confer protection from metabolic derangements by serving as a 'metabolic sink' to limit both systemic lipids and the accrual of visceral and ectopic fat (Huffman and Barzilai, 2010).

\section{IGF1 substitution effects}

The effects of the region located on chromosome 5 on growth traits have been documented for the interval between the TEXAN15 and BMS1248 microsatellite markers located 4.2 and $15.4 \mathrm{cM}$ from the $I G F 1$ candidate gene, respectively (Davis et al., 1998; Stone et al., 1999; Casas et al., 2000). Moody et al. (1996) found a significant effect of this polymorphism on weaning weight of selected and control populations of Hereford cattle, but they were careful in the interpretation of these results because the structure of the study population was not ideal. On the basis of results obtained with two different Canchim (Nelore x Charolais) lines, Machado and co-workers (2003) concluded that the IGF1 microsatellite is not directly responsible for variations in growth traits. In another study with Canchim cattle, the IGF1 polymorphism was found to be associated with phenotypic variation and breeding values only in the early phase of growth, from birth to 240 days (Andrade et al., 2008). Curi et al. (2005) found no effect of the substitutions of the IGF1 alleles on growth and carcass traits in Nelore or Angus-Nelore crossbreds. In the present study, we found no isolated effect of $I F G 1$ on growth and carcass traits, but we did find a weak synergistic effect of $I G F 1$ on the GHI-GHR-IGFI axis. This effect appeared to be more related to the $G H 1$ variation than to $G H R$ variation. Future studies should explore associations with factors other than $G H 1$ or $G H R$ such as insulin and thyroid hormones, which may affect $I G F 1$ signaling (Ronge and Blum, 1989).

\section{Regulation of growth and fat accrual at the somatotropic axis: an overall view}

The observed threshold of response of growth and fat accrual to allele substitutions in 
the bovine somatotropic axis may be attributed to differences in half-lives of GH1 and GHR. The half-life of GH1 is shorter than that of GHR, and GHR have ligands and modulators other than GH1 that modify GHR expression, surface availability and signaling (Birzniece et al., 2009). Also, GH1 autofeedback signaling is significantly affected by GHR amount, processing, maturation, ligand binding and signaling (Asa et al., 2007).

As a consequence, only a sustained increase in GH1 synthesis would overcome the thresholds for the different GH1 actions. It has been shown, for example, that GH1 treatment (1.5-2 h) of Chinese hamster ovary cells, stably transfected with GH1 receptor cDNA (CHO4), resulted in increased cellular lipid synthesis ( $240 \%$ of control). However, if GH1 treatment of $\mathrm{CHO} 4$ cells was prolonged $(16 \mathrm{~h})$, this instead decreased cellular lipid synthesis $(128 \%$ of control) (Möller et al., 1994). This pattern of change correlates with the changes observed in the transition from the shorter $G H 1$ allele to the longer $G H 1$ allele.

Circulating GH1 levels rise in response to nutrient deprivation and fall in states of nutrient excess (reviewed in Luque et al., 2011). A classical example is the seasonal regulation of the GH1/IGF1 axis in bears, in which diminished GH1/IGF1 activity by overeating promotes fat storage in preparation for winter denning (Blumenthal et al., 2011). Low GH1 secretion is associated with features of the metabolic syndrome, in particular increased visceral body fat and decreased lean body mass. The combination of fasting and GH1 exposure translates into enhanced lipolysis and reduced IGF1 activity in healthy men (Möller et al., 2009a). Yet, the GH1-mediated reduction in adipose tissue growth is due to a reduction in lipogenesis, which is the consequence of GH1 blunting the effects of many insulin-dependent events; lipolysis is not directly affected (Etherton et al., 1993; Etherton, 2000). Plasma IGF1 concentrations are exclusively dependent on basal GH1 levels, and GH1 pulses do not determine plasma IGF1 concentrations (Faje and Barkan, 2010). Release of GH1 is regulated by somatostatin (Luque et al., 2008) and ghrelin (Zhao et al., 2010).

An increase in the amount of GHR relative to GH1 and the consequences thereof would be the correlate of the substitution of the shorter GHR allele with the longer ones. We saw that this transition had a direct effect on ADG, and a threshold effect on fat accrual. Adipose tissue is a GH1-responsive tissue in which GH1 regulates energy metabolism by interacting with its specific receptor, GHR. Several lines of evidence indicate that changes in the expression levels of $G H R$ dramatically affect adiposity: i) GHR gene expression is dramatically upregulated during preadipocyte-adipocyte differentiation (Zou et al., 1997); ii) GHR gene polymorphisms modulate adiposity and IGF1 activity in adolescents (Mong et al., $2010)$; iii) growth hormone receptor gene-disrupted $\left(\mathrm{GHR}^{--}\right)$mice exhibit increased lifespan and adipose tissue mass (Berryman et al., 2010); iv) the functional inactivation of two copies of the GHR by mutations results in primary GH1 insensitivity in humans with short stature and progressive and marked obesity (Laron syndrome), whereas the presence of one wild-type allele is associated with varying levels of normality in the GH1-induced action, with symptoms ranging from short stature to Laron syndrome (Shevah et al., 2004; Fang et al., 2007; Aalbers et al., 2009), and v) treatment of Laron syndrome patients with IGF1 reduces their body fat mass, indicating that IGF1 exerts a direct effect on adipose tissue metabolism (Laron and Klinger, 1993). However, GHR blockade by pegvisomant without changes in circulating or tissue IGF1 levels, selectively suppresses lipid mobilization and oxidation after short-term fasting in healthy young men (Möller et al., 2009b). This supports the notion that decreased lipogenesis during fasting is a primary and important effect of GH1. 
The observed effects of genotypic transitions in the GH1-GHR-IGF1 axis are likely to be directly related to allele substitution effects on gene transcriptional dynamics at the GH1 and GHR sites and, consequently on metabolic regulation of the phenotypic traits. The $G 1$ allele, characterized by one AAG trinucleotide is located in the $G H 1$ promoter region, 9 bp upstream of the TATA-box transcription control site. Any change in the sequence of this site may affect the transcriptional efficiency of the locus. The AAG tandem repeat, which characterizes the $G 2$ allele, presumably increases transcriptional efficiency in the $G H 1$, as suggested by the better growth performance of $G 2 / G 2$ animals. Available data support the view that the short, wild-type $G H 1$ allele is associated with downregulated growth and upregulated fat accrual in $\mathrm{DR}$, as compared to the longer allele. Yet, the short, wild-type GHR allele is associated with downregulated growth and downregulated fat accrual in the ad libitum condition.

Complex patterns of metabolic regulation arising from distinct genotypic combinations of GH1, GHR and $I G F 1$ in different environmental conditions are likely to occur. These should be better examined by breeding appropriate parental lines of cattle, which still do not exist, and observing these animals in different environmental conditions. The development of experimental parental lines is needed because the analysis of genetic-phenotypic associations is often affected by genotypic sampling bias. For example, homozygous G1/ $G 1$ animals are very rare in commercial $B$. indicus herds, and absent in $B$. taurus herds. The short GHR allele is very common in B. indicus, but absent in B. taurus. Of the ten GH1GHR-IGF1 multi-genotypes identified in our Nelore herd, the predominant multi-genotype was homozygous for the large GH1 promoter (long/long, G2/G2 or domestic type), short GHR promoter (short/short or wild-type), and short IGF1 microsatellite (short/short or wildtype). The homozygous L variant of the L127V GH1 polymorphic site was fixed in the Nelore population. The predominant multi-genotype of the Nelore breed suggests that selection pressure in this breed has been directed towards high ADG and W550, and low FAT, under ad libitum conditions.

Our results suggest that the thrifty phenotype of cattle carrying the shorter promoter regions of GH1 and GHR is at least partly explained by downregulated growth and upregulated fat accrual. Future study should be aimed at determining the transcriptional activities of the GH1 and GHR coding sequences in different allele combinations, and the effects thereof in different nutritional conditions.

\section{ACKNOWLEDGMENTS}

Research supported by Excegen Genética S.A., Genon Genética Ltda., and grants from FAPESP (Genon, S.U. Dani), SEBRAE-MG (Excegen), FAPEMIG (Excegen, M.A.C. Dani and S.U. Dani), and CNPq (M.A.C. Dani and S.U. Dani). We thank the following individuals: C. Trancoso, D.V. Arruda, and L.M. Souza for laboratory assistance; F.S. Teles, S. Campos and A.F. Campos for assistance in setting up the data bank; P. Jardim and J.L.F. Spelta for secretarial assistance; J.H. Rabelo for field assistance; E.K. Pedroso for help establishing a collaboration with Perdizes Farm in Jaraguari (Quilombo Empreendimentos \& Participações Ltda., and A.S. Ferreira); co-workers of the Perdizes Farm for field assistance, and O.S. da Silva Filho for support. M.A.C. Dani and S.U. Dani hold the following patents with Excegen Genética S.A. that are related to the subject of this study: PI 0403770-7 A (2006) and PI 0503427-2 (2007), INPI, Brazil. 


\section{REFERENCES}

Aalbers AM, Chin D, Pratt KL, Little BM, et al. (2009). Extreme elevation of serum growth hormone-binding protein concentrations resulting from a novel heterozygous splice site mutation of the growth hormone receptor gene. Horm. Res. 71: 276-284.

Andrade PC, Grossi DA, Paz CC, Alencar MM, et al. (2008). Association of an insulin-like growth factor 1 gene microsatellite with phenotypic variation and estimated breeding values of growth traits in Canchim cattle. Anim. Genet. 39: 480-485.

Ardiyanti A, Oki Y, Suda Y, Suzuki K, et al. (2009). Effects of GH gene polymorphism and sex on carcass traits and fatty acid compositions in Japanese Black cattle. Anim. Sci. J. 80: 62-69.

Asa SL, DiGiovanni R, Jiang J, Ward ML, et al. (2007). A growth hormone receptor mutation impairs growth hormone autofeedback signaling in pituitary tumors. Cancer Res. 67: 7505-7511.

Belk KE, Tatum JD and Williams FL Jr (1991). Deposition and distribution of carcass fat for steers differing in frame size and muscle thickness. J. Anim. Sci. 69: 609-616.

Berryman DE, Christiansen JS, Johannsson G, Thorner MO, et al. (2008). Role of the GH/IGF-1 axis in lifespan and healthspan: lessons from animal models. Growth Horm. IGF Res. 18: 455-471.

Berryman DE, List EO, Palmer AJ, Chung MY, et al. (2010). Two-year body composition analyses of long-lived GHR null mice. J. Gerontol. A Biol. Sci. Med. Sci. 65: 31-40.

Birzniece V, Sata A and Ho KK (2009). Growth hormone receptor modulators. Rev. Endocr. Metab. Disord. 10: 145-156.

Bishop MD, Kappes SM, Keele JW, Stone RT, et al. (1994). A genetic linkage map for cattle. Genetics 136: 619-639.

Blumenthal S, Morgan-Boyd R, Nelson R, Garshelis DL, et al. (2011). Seasonal regulation of the growth hormone-insulin-like growth factor-I axis in the American black bear (Ursus americanus). Am. J. Physiol. Endocrinol. Metab. 301: E628-E636.

Bullock KD, Bertrand JK, Benyshek LL, Williams SE, et al. (1991). Comparison of real-time ultrasound and other live measures to carcass measures as predictors of beef cow energy stores. J. Anim. Sci. 69: 3908-3916.

Butler ST, Marr AL, Pelton SH, Radcliff RP, et al. (2003). Insulin restores GH responsiveness during lactation-induced negative energy balance in dairy cattle: effects on expression of IGF-I and GH receptor 1A. J. Endocrinol. 176: 205-217.

Casas E, Shackelford SD, Keele JW, Stone RT, et al. (2000). Quantitative trait loci affecting growth and carcass composition of cattle segregating alternate forms of myostatin. J. Anim. Sci. 78: 560-569.

Curi RA, Oliveira HN, Silveira AC and Lopes CR (2005). Effects of polymorphic microsatellites in the regulatory region of IGF1 and GHR on growth and carcass traits in beef cattle. Anim. Genet. 36: 58-62.

Dani MA, Heinneman MB and Dani SU (2008). Brazilian Nelore cattle: a melting pot unfolded by molecular genetics. Genet. Mol. Res. 7: 1127-1137.

Dani SU, Dani MA, Freire IL, Gouvea SP, et al. (2010). Survival of the thriftiest: restricted nurture reveals the thrifty nature of a growth gene in Bos indicus. Genet. Mol. Res. 9: 1032-1044.

Davis GP, Hetzel DJS, Corbet NJ, Scacheri S, et al (1998). The Mapping of Quantitative Trait Loci for Birth Weight in a Tropical Beef Herd. Proceedings of the 6th World Congress on Genetics Applied to Livestock Production, Armidale, 441-444.

DeNise SK and Regitano LCA (1996). Polimorfismo Molecular em Gerações de Bovinos da Raça Canchim. Doctoral thesis, Escola Superior de Agricultura Luiz de Queiroz, USP, Piracicaba.

Etherton TD (2000). The biology of somatotropin in adipose tissue growth and nutrient partitioning. J. Nutr. 130: 2623-2625.

Etherton TD, Louveau I, Sorensen MT and Chaudhuri S (1993). Mechanisms by which somatotropin decreases adipose tissue growth. Am. J. Clin. Nutr. 58: 287S-295S.

Faje AT and Barkan AL (2010). Basal, but not pulsatile, growth hormone secretion determines the ambient circulating levels of insulin-like growth factor-I. J. Clin. Endocrinol. Metab. 95: 2486-2491.

Fang P, Riedl S, Amselem S, Pratt KL, et al. (2007). Primary growth hormone (GH) insensitivity and insulin-like growth factor deficiency caused by novel compound heterozygous mutations of the GH receptor gene: genetic and functional studies of simple and compound heterozygous states. J. Clin. Endocrinol. Metab. 92: 2223-2231.

Garrett AJ, Rincon G, Medrano JF, Elzo MA, et al. (2008). Promoter region of the bovine growth hormone receptor gene: single nucleotide polymorphism discovery in cattle and association with performance in Brangus bulls. J. Anim. Sci. 86: 3315-3323.

Ge W, Davis ME, Hines HC, Irvin KM, et al. (2001). Association of a genetic marker with blood serum insulin-like growth factor-I concentration and growth traits in Angus cattle. J. Anim. Sci. 79: 1757-1762.

Ge W, Davis ME, Hines HC, Irvin KM, et al. (2003). Association of single nucleotide polymorphisms in the growth hormone and growth hormone receptor genes with blood serum insulin-like growth factor I concentration and growth traits in Angus cattle. J. Anim. Sci. 81: 641-648.

Gordon DF, Quick DP, Erwin CR, Donelson JE, et al. (1983). Nucleotide sequence of the bovine growth hormone chromosomal gene. Mol. Cell Endocrinol. 33: 81-95.

Grochowska R, Sorensen P, Zwierzchowski L, Snochowski M, et al. (2001). Genetic variation in stimulated GH release 
and in IGF-I of young dairy cattle and their associations with the leucine/valine polymorphism in the GH gene. $J$. Anim. Sci. 79: 470-476.

Hale CS, Herring WO, Shibuya H, Lucy MC, et al. (2000). Decreased growth in angus steers with a short TG-microsatellite allele in the P1 promoter of the growth hormone receptor gene. J. Anim. Sci. 78: 2099-2104.

Huffman DM and Barzilai N (2010). Contribution of adipose tissue to health span and longevity. Interdiscip. Top. Gerontol. 37: 1-19.

Islam KK, Vinsky M, Crews RE, Okine E, et al. (2009). Association analyses of a SNP in the promoter of IGF1 with fat deposition and carcass merit traits in hybrid, Angus and Charolais beef cattle. Anim. Genet. 40: 766-769.

Katoh K, Kouno S, Okazaki A, Suzuki K, et al. (2008). Interaction of GH polymorphism with body weight and endocrine functions in Japanese black calves. Domest. Anim. Endocrinol. 34: 25-30.

Kim ES, Shi X, Cobanoglu O, Weigel K, et al. (2009). Refined mapping of twinning-rate quantitative trait loci on bovine chromosome 5 and analysis of insulin-like growth factor-1 as a positional candidate gene. J. Anim. Sci. 87: 835-843.

Kirkpatrick BW (1992). Identification of a conserved microsatellite site in the porcine and bovine insulin-like growth factor-I gene 5' flank. Anim. Genet. 23: 543-548.

Laron Z and Klinger B (1993). Body fat in Laron syndrome patients: effect of insulin-like growth factor I treatment. Horm. Res. 40: 16-22.

Lee BK, Lin GF, Crooker BA, Murtaugh MP, et al. (1996). Association of somatotropin (BST) gene polymorphism at the 5th exon with selection for milk yield in Holstein cows. Domest. Anim. Endocrinol. 13: 373-381.

Li C, Basarab J, Snelling WM, Benkel B, et al. (2004). Assessment of positional candidate genes myf5 and igfl for growth on bovine chromosome 5 in commercial lines of Bos taurus. J. Anim. Sci. 82: 1-7.

Lima SPG (2003). Estudo de um Polimorfismo na Região Promotora do Gen do Hormônio de Crescimento Bovino (bGH) em Rebanhos Nelore Selecionados para Peso Pós Desmama. Master's thesis, UNESP, Jaboticabal.

Lucy MC, Hauser SD, Eppard PJ, Krivi GG, et al. (1991). Genetic polymorphism within the bovine somatotropin (bST) gene detected by polymerase chain reaction and endonuclease digestion. J. Dairy Sci. 74 (Suppl 1): 284.

Lucy MC, Johnson GS, Shibuya H, Boyd CK, et al. (1998). Rapid communication: polymorphic (GT)n microsatellite in the bovine somatotropin receptor gene promoter. J. Anim. Sci. 76: 2209-2210.

Luque RM, Park S and Kineman RD (2008). Role of endogenous somatostatin in regulating GH output under basal conditions and in response to metabolic extremes. Mol. Cell Endocrinol. 286: 155-168.

Luque RM, Gahete MD, Cordoba-Chacon J, Childs GV, et al. (2011). Does the pituitary somatotrope play a primary role in regulating GH output in metabolic extremes? Ann. N. Y. Acad. Sci. 1220: 82-92.

MacEachern S, McEwan J and Goddard M (2009). Phylogenetic reconstruction and the identification of ancient polymorphism in the Bovini tribe (Bovidae, Bovinae). BMC Genomics 10: 177.

Machado MBB, Alencar MM, Pereira AP, Oliveira HN, et al. (2003). QTL affecting body weight in a candidate region of cattle chromosome 5. Genet. Mol. Biol. 26: 259-265.

Maj A, Snochowski M, Siadkowska E, Rowinska B, et al. (2008). Polymorphism in genes of growth hormone receptor (GHR) and insulin-like growth factor-1 (IGF1) and its association with both the IGF1 expression in liver and its level in blood in Polish Holstein-Friesian cattle. Neuro. Endocrinol. Lett. 29: 981-989.

Matsuhashi T, Maruyama S, Uemoto Y, Kobayashi N, et al. (2011). Effects of bovine fatty acid synthase, stearoylcoenzyme A desaturase, sterol regulatory element-binding protein 1, and growth hormone gene polymorphisms on fatty acid composition and carcass traits in Japanese Black cattle. J. Anim. Sci. 89: 12-22.

Mitra A, Schlee P, Balakrishnan CR and Pirchner F (1995). Polymorphisms at growth-hormone and prolactin loci in Indian cattle and buffalo. J. Anim. Breed. Genet. 112: 71-74.

Möller C, Emtner M, Arner P and Norstedt G (1994). Growth hormone regulation of lipid metabolism in cells transfected with growth hormone receptor cDNA. Mol. Cell Endocrinol. 99: 111-117.

Möller L, Dalman L, Norrelund H, Billestrup N, et al. (2009a). Impact of fasting on growth hormone signaling and action in muscle and fat. J. Clin. Endocrinol. Metab. 94: 965-972.

Möller L, Norrelund H, Jessen N, Flyvbjerg A, et al. (2009b). Impact of growth hormone receptor blockade on substrate metabolism during fasting in healthy subjects. J. Clin. Endocrinol. Metab. 94: 4524-4532.

Mong JL, Ng MC, Guldan GS, Tam CH, et al. (2010). Associations of the growth hormone receptor (GHR) gene polymorphisms with adiposity and IGF-I activity in adolescents. Clin. Endocrinol. 73: 313-322.

Moody DE, Pomp D, Newman S and MacNeil MD (1996). Characterization of DNA polymorphisms in three populations of hereford cattle and their associations with growth and maternal EPD in line 1 herefords. J. Anim. Sci. 74: 1784-1793.

Oberbauer AM, Stiglich C, Murray JD, Keen CL, et al. (2004). Dissociation of body growth and adipose deposition effects of growth hormone in oMt1a-oGH transgenic mice. Growth Dev. Aging 68: 33-45.

Paz CCP (2002). Associação entre Polimorfismos Genéticos e Parâmetros da Curva de Crescimento em Bovinos de Corte. Doctoral thesis, Escola Superior de Agricultura Luiz de Queiroz, USP, Piracicaba. 
Radcliff RP, McCormack BL, Keisler DH, Crooker BA, et al. (2006). Partial feed restriction decreases growth hormone receptor 1A mRNA expression in postpartum dairy cows. J. Dairy Sci. 89: 611-619.

Reyna XF, Montoya HM, Castrellon VV, Rincon AM, et al. (2010). Polymorphisms in the IGF1 gene and their effect on growth traits in Mexican beef cattle. Genet. Mol. Res. 9: 875-883.

Ritz LR, Glowatzki-Mullis ML, MacHugh DE and Gaillard C (2000). Phylogenetic analysis of the tribe Bovini using microsatellites. Anim. Genet. 31: 178-185.

Rodrigues CV, Guimaraes SE, Dias Neto E and Pinheiro LE (1998). Identification of a novel polymorphism in the promoter region of the bovine growth hormone gene. Anim. Genet. 29: 65-66.

Rodrigues CV, Dias Neto ED and Pinheiro LE (1999). A variation of simple repeat sequence in the promoter region of the bovine growth hormone (bGH) gene in beef cattle is similar to water buffalo. J. Anim. Breed. Genet. 116: 15-19.

Ronge H and Blum J (1989). Insulin-like growth factor I during growth in bulls. Reprod. Nutr. Dev. 29: 105-111.

Rosa AJM (1997). Caracterização da Raça Nelore e Teste de Paternidade por Marcadores Moleculares. Master's thesis, Escola Superior de Agricultura Luiz de Queiroz, USP, Piracicaba.

Rosa AMJ, Regitano LCA, Merzel M, Packer IU, et al (1996). Polymorphism of Growth Hormone, Microsatellite IGF-I and Association With Feedlot Performance in Nelore Cattle. Anais do $42^{\circ}$ Congresso Nacional de Genética, Caxambu, 297.

Sanguinetti CJ, Dias Neto E and Simpson AJ (1994). Rapid silver staining and recovery of PCR products separated on polyacrylamide gels. Biotechniques 17: 914-921.

Schlee P, Graml R, Rottmann O and Pirchner F (1994). Influence of growth-hormone genotypes on breeding values of Simmental bulls. J. Anim. Breed. Genet. 111: 253-256.

Shevah O, Galli-Tsinopoulou A, Rubinstein M, Nousia-Arvanitakis S, et al. (2004). Classical phenotype of Laron syndrome in a girl with a heterozygous mutation and heterozygous polymorphism of the growth hormone receptor gene. J. Pediatr. Endocrinol. Metab. 17: 371-374.

Shimokawa I, Higami Y, Tsuchiya T, Otani H, et al. (2003). Life span extension by reduction of the growth hormoneinsulin-like growth factor-1 axis: relation to caloric restriction. FASEB J. 17: 1108-1109.

Smith JM, Van Amburgh ME, Diaz MC, Lucy MC, et al. (2002). Effect of nutrient intake on the development of the somatotropic axis and its responsiveness to GH in Holstein bull calves. J. Anim. Sci. 80: 1528-1537.

Sorensen P, Grochowska R, Holm L, Henryon M, et al. (2002). Polymorphism in the bovine growth hormone gene affects endocrine release in dairy calves. J. Dairy Sci. 85: 1887-1893.

Sprinkle JE, Ferrell CL, Holloway JW, Warrington BG, et al. (1998). Adipose tissue partitioning of limit-fed beef cattle and beef cattle with ad libitum access to feed differing in adaptation to heat. J. Anim. Sci. 76: 665-673.

Statistical Analysis System (2000). SAS Institute Inc., Cary.

Stone RT, Keele JW, Shackelford SD, Kappes SM, et al. (1999). A primary screen of the bovine genome for quantitative trait loci affecting carcass and growth traits. J. Anim. Sci. 77: 1379-1384.

Zha Y, Taguchi T, Nazneen A, Shimokawa I, et al. (2008). Genetic suppression of GH-IGF-1 activity, combined with lifelong caloric restriction, prevents age-related renal damage and prolongs the life span in rats. Am. J. Nephrol. 28: 755-764.

Zhao TJ, Liang G, Li RL, Xie X, et al. (2010). Ghrelin O-acyltransferase (GOAT) is essential for growth hormonemediated survival of calorie-restricted mice. Proc. Natl. Acad. Sci. U. S. A. 107: 7467-7472.

Zou L, Menon RK and Sperling MA (1997). Induction of mRNAs for the growth hormone receptor gene during mouse 3T3-L1 preadipocyte differentiation. Metabolism 46: 114-118. 